\title{
Plasma immersion ion implantation: Influence on the rotating bending fatigue strength of AA 7050-T7451 aluminum alloy
}

\author{
Thiago Alexandre Minto*, Verônica Mara Cortez Alves de Oliveira, Herman Jacobus Cornelis Voorwald \\ Faculdade de Engenharia de Guaratinguetá, UNESP - Universidade Estadual Paulista, Materials and Technology Department, Fatigue and Aeronautical Materials Research Group,
} Av. Ariberto Pereira da Cunha, 333 - Guaratinguetá, SP 12516410, Brazil

\section{A R T I C L E I N F O}

\section{Article history:}

Received 6 July 2016

Received in revised form 24 February 2017

Accepted 3 May 2017

Available online 20 May 2017

\section{Keywords:}

Plasma immersion ion implantation

Fatigue

AA7050-T7451 aluminum alloy

Residual stress

\begin{abstract}
A B S T R A C T
Failures in structural components due to cyclic loading are associated with the surface damage. The aircraft industry has been searched into the alternative coatings that enhance performance by reducing the environmental impact. Coatings deposited by different surface processes are more or less effective to improve fatigue life of diverse elements. The sulphuric and chromic anodizing methods were applied on AA 7050-T7451 aluminum alloy. The study results were compared with the plasma immersion ion implantation for different experimental parameters. This investigation aims to study plasma immersion ion implantation (PIII) effect on the fatigue life of rotating and bending on AA 7050-T7451 aluminum alloy. Experimental results indicate that the implantation setup of low impact frequency increases the fatigue life and improves the roughness without decrease in the microhardness of base material. The implantation of high impact frequency reduces the fatigue life of base material even more than both anodizing processes.
\end{abstract}

(c) 2017 Elsevier Ltd. All rights reserved.

\section{Introduction}

Mechanical properties evaluation is very important for material design in the aerospace industry. Structural components are subjected to cyclic loads during take-off, flight and landing and, therefore, fatigue properties need to be evaluated. In addition to fatigue strength, corrosion and wear resistance are important to be considered [1-4].

The aluminum alloy 7000 series are commonly used in the aerospace industry due to high mechanical strength, high strength to weight ratio, and low cost. However, aerospace aggressive environment requires coated materials to prevent wear and corrosion damage [1-3,5,6].

Anodic films are commonly used in aluminum alloys to improve components corrosion resistance in saline environments. Although, it is well known that the anodization coating reduces the fatigue life of base material. Tensile residual stresses and microcracks generated from anodizing processes are responsible for the fatigue resistance decrease of treated components. Recently studies have been conducted to search for alternative treatments with lower environment impact and without reducing base material fatigue life [1-3,5,7-11].

\footnotetext{
* Corresponding author.

E-mail address: thiagominto@hotmail.com (T.A. Minto).
}

Tensile residual stresses and microcracks were also associated to the decrease in AA 7050-T7451 aluminum alloy fatigue strength $[1,2]$. Furthermore, it was observed that higher reduction occurred with sulphuric anodizing in comparison to chromic anodizing.

Plasma immersion ion implantation has been most extensively used to improve hardness and, therefore, reduce wear damage of metals. The ability to treat complex geometries parts is also an important point to be considered [12-17].

According Liu et al., AISI 52100 fatigue life was increased in about $236.3 \%$ as a result of Nitrogen PIII treatment. The treatment also changed the microhardness and reduced approximately $83.3 \%$ the material roughness [17].

This research aims at investigating the effect of PIII treatment parameters on the rotating bending fatigue strength of AA 7050-T7451 aluminum alloy. The behavior of residual stresses and the crack initiation points of fatigued specimens were also evaluated. Implantation was carrying out with $\mathrm{N}_{2}$ and parameters as voltage, frequency and time were investigated. Scanning electron microscopy was used to study fatigue fracture surfaces and identify crack nucleation points.

\section{Materials and methods}

The chemical composition of AA 7050 aluminum alloy is shown by Table 1 . 
Table 1

Chemical composition of AA 7050

\begin{tabular}{|c|c|c|c|c|c|c|c|c|c|c|}
\hline Elements & $\mathrm{Al}$ & $\mathrm{Cr}$ & $\mathrm{Cu}$ & $\mathrm{Fe}$ & $\mathrm{Mg}$ & Mn & $\mathrm{Si}$ & $\mathrm{Ti}$ & $\mathrm{Zn}$ & $\mathrm{Zr}$ \\
\hline Concentration (\%) & $\cong 89.6$ & 0.023 & 2.15 & 0.12 & 1.90 & 0.013 & 0.08 & 0.037 & 5.99 & 0.10 \\
\hline
\end{tabular}

The mechanical properties were obtained by a heat treatment at $470-480^{\circ} \mathrm{C}$ cooled to $43^{\circ} \mathrm{C}$, followed by heating at $115-125^{\circ} \mathrm{C}$ for $3-6 \mathrm{~h}$. Lastly heating at $160-170{ }^{\circ} \mathrm{C}$ for $24-30 \mathrm{~h}$. Hardness: $162 \mathrm{HV}$, Ultimate Tensile Strength: $524 \mathrm{MPa}$.

To perform the PIII treatment, the component is placed in a vacuum chamber in which plasma containing the ions to be implanted is generated. The chamber was pumped to a base pressure of $0.2 \mathrm{~Pa}$ before the PIII treatment. Ions are accelerated through the sheath formed around the substrate and implanted. Nitrogen implantation was realized by applying to the substrate negative high voltage pulses of $5.0,6.0,9.0$ e $10.0 \mathrm{kV}$, pulse length of $50 \mu \mathrm{s}$ and repetition frequency ranging between 0.1 and $1.0 \mathrm{kHz}$. The PIII specimen surfaces were analysed by microhardness tests, roughness and residual stresses.

Rotating bending fatigue tests were performed at $3500 \mathrm{rpm}$ and load ratio equal to $\mathrm{R}=-1.0$, at room temperature. Specimens were prepared according to standards DIN 50113 and ISO 1143. Fatigue test were conducted to complete fracture of the specimen or $10^{6}$ run-out cycles. Twelve specimens were used in each experimental condition.

Eight groups of rotating bending fatigue specimens were prepared to obtain experimental S-N curves:

- AA 7050-T7451 aluminum alloy;

- AA 7050-T7451/6.0 kV/0.5 kHz/2 h PIII treated;

- AA 7050-T7451/6.0 kV/0.5 kHz/3 h PIII treated;

- AA 7050-T7451/6.0 kV/0.2 kHz/1 h PIII treated;

- AA 7050-T7451/6.0 kV/0.2 kHz/1 h/cooling PIII treated;

- AA 7050-T7451/5.0 kV/1.0 kHz/2 h PIII treated;

- AA 7050-T7451/9.0 kV/0.2 kHz/3 h PIII treated;

- AA 7050-T7451/10.0 kV/0.1 kHz/2 h PIII treated.

Residual stress induced by PIII treatments were evaluated by the X-ray diffraction method. The accuracy of the stress measurement was $\Delta \sigma= \pm 10 \mathrm{MPa}$.

\section{Results and discussions}

The plasma immersion ion implantation temperatures profile for the experimental conditions studied, are indicated in Table 2.

The PIII treatment experiments chosen were responsible for temperature profile lower than aluminum base material first ageing temperature ( 3 and 4 ), between the first e second ageing temperature (1,6 and 7) and higher than second ageing heat treatment temperature ( 2 and 5 ). Experimental parameters in Table 2 indicate that the implantation parameters will influence initial temperatures at time zero. The explanation is as follows: before the nitrogen implantation treatment, the system is subjected to a cleaning procedure with argon gas. For all conditions studied in this research, the process started with the impact frequency used in each case and voltage is changed from $5.0 \mathrm{kV}$ to the values used in each condition $(5.0 \mathrm{kV}, 6.0 \mathrm{kV}, 9.0 \mathrm{kV}$ and $10.0 \mathrm{kV})$.

Initial temperatures near to each other are observed in Table 2 for experiments $1 / 2$ respectively $(6.0 \mathrm{kV} / 0.5 \mathrm{kHz} / 2 \mathrm{~h})$ and $(6.0 \mathrm{kV} / 0.5 \mathrm{kHz} / 3 \mathrm{~h})$ and $3 / 4 / 7$, respectively $(6.0 \mathrm{kV} / 0.2 \mathrm{kHz} / 1 \mathrm{~h})$, $(6.0 \mathrm{kV} / 0.2 \mathrm{kHz})(210 \mathrm{~min}$.) and $(10.0 \mathrm{kV} / 0.1 \mathrm{kHz} / 2 \mathrm{~h})$. On the other hand, comparison between experiments $1 / 2$ with $3 / 4 / 7$ indicates higher initial temperatures for the former, associated to increase in frequency that increases directly the particle collisions volume and, consequently, the system initial temperature. Comparison between 3 and 6 , with impact frequency of $0.2 \mathrm{kHz}$, shows that increase in applied voltage from $6.0 \mathrm{kV}$ to $9.0 \mathrm{kV}$ results in a higher initial treatment temperature.

As indicated in Table 2, the highest temperature for $6.0 \mathrm{kV} / 0.2 \mathrm{kHz} / 210 \mathrm{~min}$. was $75.6^{\circ} \mathrm{C}$, in which $30 \mathrm{~min}$ of cooling time occurred at each $30 \mathrm{~min}$ of the PIII treatment. The objective was to decrease the temperature inside the chamber and to study the influence on fatigue strength.

As already mentioned, the highest temperature was measured after $210 \mathrm{~min}\left(75.6^{\circ} \mathrm{C}\right), 16.2^{\circ} \mathrm{C}$ lower than that obtained for $(6.0 \mathrm{kV} / 0.2 \mathrm{kHz} / 1 \mathrm{~h})$ (experiment 3). For both PIII treatment parameters, experiments 3 and 4 in Table 2, the highest temperature was lower than the first precipitation heat treatment temperature, $115-125^{\circ} \mathrm{C}$.

Fig. 1 shows PIII treatments in which temperature profiles are represented between the first $\left(115-125^{\circ} \mathrm{C}\right)$ and second ageing heat treatment temperatures $\left(160-170^{\circ} \mathrm{C}\right)$. Two curves behave in a very similar way: $6.0 \mathrm{kV} / 0.5 \mathrm{kHz} / 2 \mathrm{~h}$ and $9.0 \mathrm{kV} / 0.2 \mathrm{kHz} / 3 \mathrm{~h}$. This indicates a possible correlation between voltage and impact frequency.

Final PIII treatment temperatures higher than the reference for the second precipitation heat treatment $\left(160-170{ }^{\circ} \mathrm{C}\right)$ were obtained for $(6.0 \mathrm{kV} / 0.5 \mathrm{kHz} / 3 \mathrm{~h})$ and $(5.0 \mathrm{kV} / 1.0 \mathrm{kHz} / 2 \mathrm{~h})$. It is clear from Table 2 and Fig. 1, that the highest PIII treatment temperature resulted from the highest impact frequency $(1.0 \mathrm{kHz})$.

In this case, a decrease in temperature is observed from $251.1^{\circ} \mathrm{C} / 60 \mathrm{~min}$. to $242.1^{\circ} \mathrm{C} / 120 \mathrm{~min}$. Still considering Fig. 1 , it is possible to correlate the increase in slope from curves temperature $x$ time with the increase in impact frequency. In the case of constant frequency, slope is also directly dependent on the applied voltage.

Microhardness Vickers for conditions studied are represented in Table 3.

Table 2

Plasma immersion ion implantation temperatures.

\begin{tabular}{|c|c|c|c|c|c|c|c|c|c|c|}
\hline \multirow[t]{2}{*}{ Experiments } & \multirow[t]{2}{*}{$\mathrm{kV}$} & \multirow[t]{2}{*}{ Frequency kHz } & \multicolumn{8}{|c|}{ Temperature ${ }^{\circ} \mathrm{C}$} \\
\hline & & & $0 \mathrm{~min}$. & $30 \mathrm{~min}$. & $60 \mathrm{~min}$. & $90 \mathrm{~min}$. & $120 \mathrm{~min}$. & $150 \mathrm{~min}$. & $180 \mathrm{~min}$. & $210 \mathrm{~min}$. \\
\hline 1 & 6.0 & 0.5 & 66.8 & 107.5 & 139.1 & 144.9 & 148.7 & - & - & - \\
\hline 2 & 6.0 & 0.5 & 80.1 & 115.4 & 129.8 & 139.7 & 139.0 & 145.1 & 175.8 & - \\
\hline 3 & 6.0 & 0.2 & 57.6 & 77.4 & 91.8 & - & - & - & - & - \\
\hline 4 & 6.0 & 0.2 & 59.4 & 68.4 & - & 64.8 & 72.0 & - & 61.2 & 75.6 \\
\hline 5 & 5.0 & 1.0 & 111.3 & 215.3 & 251.1 & 243.9 & 242.1 & - & - & - \\
\hline 6 & 9.0 & 0.2 & 94.1 & 119.0 & 139.7 & 144.9 & 148.5 & 147.6 & 148.7 & - \\
\hline 7 & 10.0 & 0.1 & 51.8 & 81.7 & 99.7 & 108.7 & 116.8 & - & - & - \\
\hline
\end{tabular}




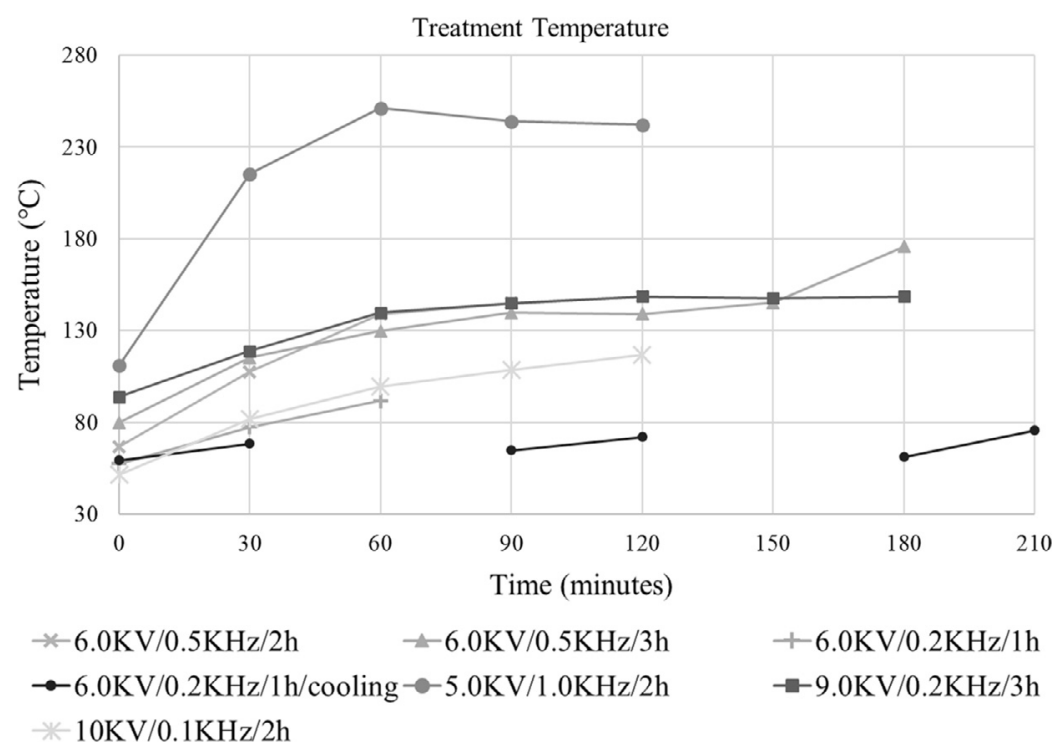

Fig. 1. PIII treatments temperature.

Table 3

Microhardness Vickers.

\begin{tabular}{|c|c|c|c|c|c|c|c|c|}
\hline Point & $\begin{array}{l}\text { Base } \\
\text { Material }\end{array}$ & $6.0 \mathrm{kV} 0.5 \mathrm{kHz} 2 \mathrm{~h}$ & $6.0 \mathrm{kV} 0.5 \mathrm{kHz} 3 \mathrm{~h}$ & $6.0 \mathrm{kV} 0.2 \mathrm{kHz} 1 \mathrm{~h}$ & $\begin{array}{l}6.0 \mathrm{kV} 0.2 \mathrm{kHz} 1 \mathrm{~h} \\
\text { Cooling }\end{array}$ & $5.0 \mathrm{kV} 1.0 \mathrm{kHz} 2 \mathrm{~h}$ & $9.0 \mathrm{kV} 0.2 \mathrm{kHz} 3 \mathrm{~h}$ & $10.0 \mathrm{kV} 0.1 \mathrm{kHz} 2 \mathrm{~h}$ \\
\hline Surface & 155 & 143 & 134 & 164 & 165 & 139 & 136 & 181 \\
\hline $0.05 \mathrm{~mm}$ & 152 & 150 & 137 & 159 & 163 & 142 & 138 & 168 \\
\hline $0.10 \mathrm{~mm}$ & 155 & 149 & 142 & 157 & 159 & 146 & 142 & 178 \\
\hline $0.15 \mathrm{~mm}$ & 152 & 153 & 142 & 150 & 156 & 148 & 146 & 168 \\
\hline Nucleus & 156 & 152 & 149 & 153 & 153 & 149 & 153 & 155 \\
\hline
\end{tabular}

Table 3 shows that for experiments $(6.0 \mathrm{kV} / 0.5 \mathrm{kHz} / 3 \mathrm{~h})$, $(9.0 \mathrm{kV} / 0.2 \mathrm{kHz} / 3 \mathrm{~h}),(5.0 \mathrm{kV} / 1.0 \mathrm{kHz} / 2 \mathrm{~h})$ and $(6.0 \mathrm{kV} / 0.5 \mathrm{kHz} / 2 \mathrm{~h})$ surface microhardness value is respectively $13 \%, 12 \%, 10 \%$ and $8 \%$ lower compared to base material. Mentioned conditions achieved higher PIII treatment temperatures than the base material first

Table 4

Superficial roughness $(\mu \mathrm{m})$.

\begin{tabular}{llllll}
\hline \multirow{2}{*}{ Experiments } & \multicolumn{2}{l}{ Average sample 1 } & & \multicolumn{2}{l}{ Average sample 2 } \\
\cline { 2 - 3 } & Polished & Treated & & Polished & Treated \\
\hline $5.0 \mathrm{kV} / 1.0 \mathrm{kHz} / 2 \mathrm{~h}$ & 0.245 & 0.182 & & 0.218 & 0.158 \\
$6.0 \mathrm{kV} / 0.2 \mathrm{kHz} / 1 \mathrm{~h}$ & 0.107 & 0.065 & & 0.293 & 0.140 \\
$6.0 \mathrm{kV} / 0.2 \mathrm{kHz} / 1 \mathrm{~h}$ Cooling & 0.313 & 0.170 & & 0.430 & 0.067 \\
\hline
\end{tabular}

ageing temperature. High impact frequency and PIII treatment time are associated to the decrease in microhardness. Higher surface microhardness was obtained in experiments $(6.0 \mathrm{kV} / 0.2 \mathrm{kHz} / 1 \mathrm{~h})$, $(6.0 \mathrm{kV} / 0.2 \mathrm{kHz} / 1 \mathrm{~h} /$ cooling) and $(10.0 \mathrm{kV} / 0.1 \mathrm{kHz} / 2 \mathrm{~h})$, respectively $6 \%, 6 \%$ and $17 \%$ compared to AA 7050-T7451 aluminum alloy.

Roughness tests in polished specimens showed decrease in superficial roughness after the PIII treatments. This behavior was observed for experiments from 1 to 7 . In Table 4, data for condition $(5.0 \mathrm{kV} / 1.0 \mathrm{kHz} / 2 \mathrm{~h}), \quad(6.0 \mathrm{kV} / 0.2 \mathrm{kHz} / 1 \mathrm{~h})$ and $(6.0 \mathrm{kV} / 0.2 \mathrm{kHz} /$ $1 \mathrm{~h} /$ cooling) are represented for two test specimens. Data in Table 4 indicates a tendency to associate higher reduction with lower impact frequency in PIII treatments.

Table 5 shows initial and maximum PIII treatment temperatures and low/high cycle fatigue average number of cycles to failure. SxN curves for conditions studied are represented in Fig. 2.

Table 5

Average number of cycles to failure.

\begin{tabular}{|c|c|c|c|c|c|}
\hline Condition & $\begin{array}{l}\text { Surface Microhardness } \\
\text { (HV) }\end{array}$ & $\begin{array}{l}\text { Initial temperature } \\
\left({ }^{\circ} \mathrm{C}\right)\end{array}$ & $\begin{array}{l}\text { Maximum temperature } \\
\left({ }^{\circ} \mathrm{C}\right)\end{array}$ & $\begin{array}{l}\text { Number of cycles } \\
\sigma=328 \mathrm{MPa}\end{array}$ & $\begin{array}{l}\text { Number of cycles } \\
\sigma=188 \mathrm{MPa}\end{array}$ \\
\hline Base Material & 155 & - & - & 13108 & 913268 \\
\hline Sulphuric Anodizing & - & - & - & 9143 & 199410 \\
\hline Chromic Anodizing & - & - & - & 9807 & 645946 \\
\hline $6.0 \mathrm{kV} / 0.5 \mathrm{kHz} / 2 \mathrm{~h}$ & 143 & 66.8 & 148.7 & 14895 & 434220 \\
\hline $6.0 \mathrm{kV} / 0.5 \mathrm{kHz} / 3 \mathrm{~h}$ & 134 & 80.1 & 175.8 & 7876 & 184379 \\
\hline $6.0 \mathrm{kV} / 0.2 \mathrm{kHz} / 1 \mathrm{~h}$ & 164 & 57.6 & 91.8 & 13892 & 1026082 \\
\hline $\begin{array}{l}6.0 \mathrm{kV} / 0.2 \mathrm{kHz} / 1 \mathrm{~h} / \\
\quad \text { cooling }\end{array}$ & 165 & 59.4 & 75.6 & 10076 & 836364 \\
\hline $5.0 \mathrm{kV} / 1.0 \mathrm{kHz} / 2 \mathrm{~h}$ & 139 & 111.3 & 242.1 & 4016 & 119729 \\
\hline $9.0 \mathrm{kV} / 0.2 \mathrm{kHz} / 3 \mathrm{~h}$ & 136 & 94.1 & 148.7 & 12600 & 530822 \\
\hline $10.0 \mathrm{kV} / 0.1 \mathrm{kHz} / 2 \mathrm{~h}$ & 181 & 51.8 & 116.8 & 31054 & 885238 \\
\hline
\end{tabular}




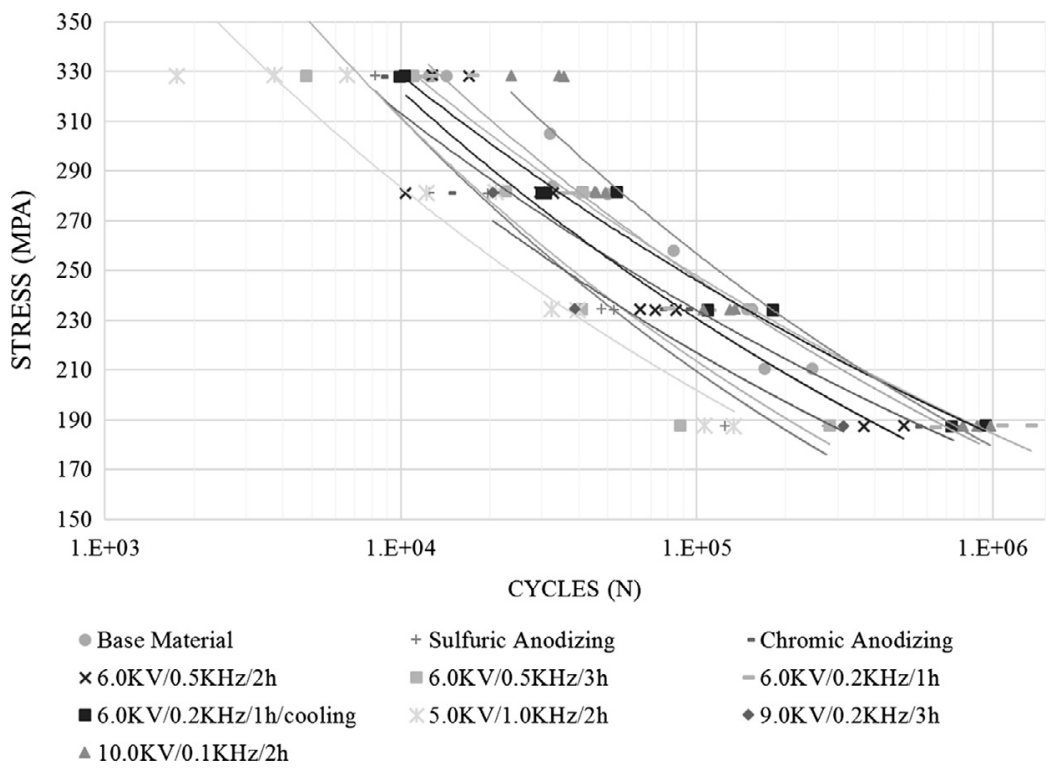

Fig. 2. Rotating bending SXN curves.

Table 6

Nanohardness (GPa).

\begin{tabular}{llll}
\hline Depth $(\mu \mathrm{m})$ & Base material & $(5.0 \mathrm{kV} / 1.0 \mathrm{kHz} / 2 \mathrm{~h})$ & $(10.0 \mathrm{kV} / 0.1 \mathrm{kHz} / 2 \mathrm{~h})$ \\
\hline 0 & 1.88 & 1.37 & 3.25 \\
10 & 1.98 & 1.66 & 2.57 \\
20 & 2.01 & 1.76 & 2.62 \\
30 & 1.91 & 1.81 & 2.60 \\
40 & 1.92 & 1.70 & 3.19 \\
50 & 1.92 & 1.74 & 3.31 \\
60 & 2.29 & 1.79 & 3.75 \\
70 & 2.00 & 1.74 & 3.87 \\
80 & 1.87 & 1.74 & 4.16 \\
90 & 1.86 & 1.76 & 4.56 \\
\hline
\end{tabular}

Data analysis from Table 5 for base material, sulphuric anodizing and chromic anodizing showed lower average number of cycles to failure in comparison to AA 7050-T7451 aluminum alloy. This tendency is observed for low and high cycle fatigue. Experimental conditions responsible for lower surface microhardness in comparison to base material may be divided the fatigue behavior into two groups: $(6.0 \mathrm{kV} / 0.5 \mathrm{kHz} / 2 \mathrm{~h}) /(9.0 \mathrm{kV} / 0.2 \mathrm{kHz} / 3 \mathrm{~h})$ with the PIII treatment temperatures higher than the first ageing temperature $\left(115-125^{\circ} \mathrm{C}\right)$, but lower than the second ageing temperature $\left(160-170^{\circ} \mathrm{C}\right)$; and $(6.0 \mathrm{kV} / 0.5 \mathrm{kHz} / 3 \mathrm{~h}) /(5.0 \mathrm{kV} / 1.0 \mathrm{kHz} / 2 \mathrm{~h})$ with PIII treatment temperatures higher than the second ageing temperature $\left(160-170^{\circ} \mathrm{C}\right)$. A tendency shown in Table 5 indicates lower average number of cycles to failure for the second group.

In Table 5, plasma immersion ion implantation experimental parameters $\quad(6.0 \mathrm{kV} / 0.2 \mathrm{kHz} / 1 \mathrm{~h}) /(6.0 \mathrm{kV} / 0.2 \mathrm{kHz} / 1 \mathrm{~h} /$ cooling $) /$ $(10.0 \mathrm{kV} / 0.1 \mathrm{kHz} / 2 \mathrm{~h})$ are associated to treatment temperatures lower than the first ageing temperature and to higher surface microhardness in comparison to AA 7050-T7451 aluminum alloy and to the two groups already mentioned. From the seven combinations voltage/frequency/time, those that resulted in treatment

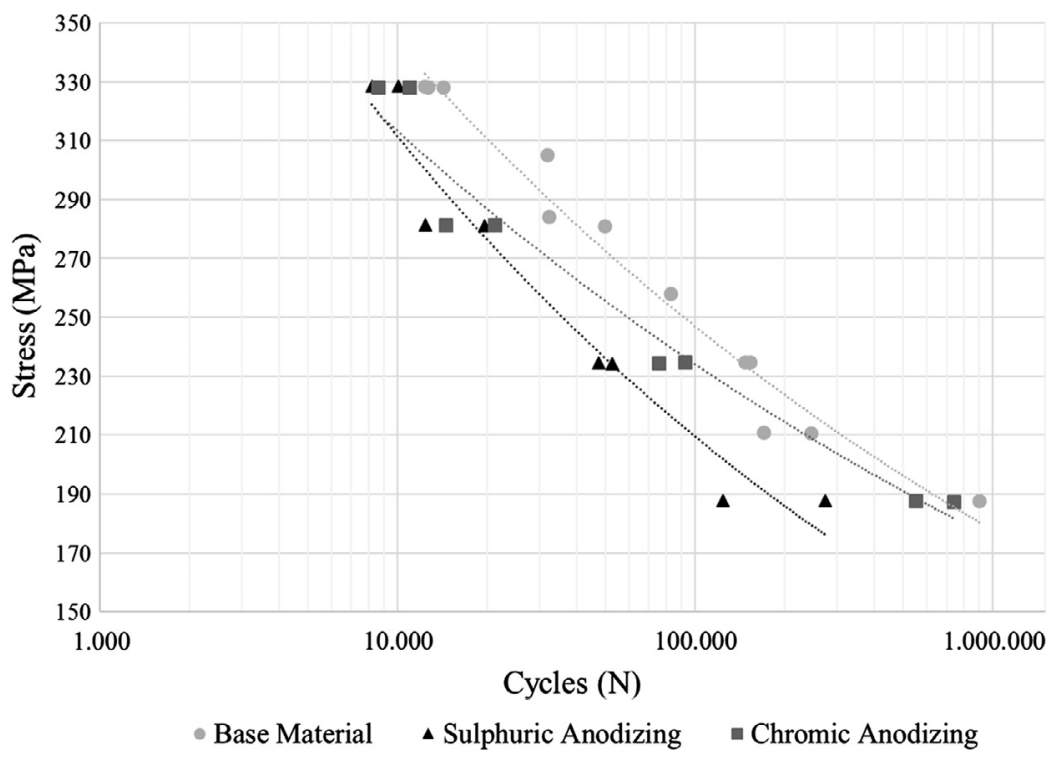

Fig. 3. S-N curves. AA 7050-T7451. Sulphuric anodizing/Chromic anodizing. 
Table 7

Longitudinal and transversal residual stresses (MPa).

\begin{tabular}{lll}
\hline Experiment & Longitudinal & Transversal \\
\hline Sulphuric anodizing & $100 \pm 7$ & $-35 \pm 5$ \\
Chromic anodizing & $-65 \pm 8$ & $-50 \pm 3$ \\
$6.0 \mathrm{kV} / 0.5 \mathrm{kHz} / 2 \mathrm{~h}$ & $-80 \pm 6$ & $-15 \pm 5$ \\
$6.0 \mathrm{kV} / 0.5 \mathrm{kHz} / 3 \mathrm{~h}$ & $-10 \pm 2$ & $-60 \pm 1$ \\
$6.0 \mathrm{kV} / 0.2 \mathrm{kHz} / 1 \mathrm{~h}$ & $20 \pm 8$ & $20 \pm 8$ \\
$6.0 \mathrm{kV} / 0.2 \mathrm{kHz} / 1 \mathrm{~h} /$ cooling & $-10 \pm 0$ & $115 \pm 0$ \\
$5.0 \mathrm{kV} / 1.0 \mathrm{kHz} / 2 \mathrm{~h}$ & $-45 \pm 5$ & $-112 \pm 15$ \\
$9.0 \mathrm{kV} / 0.2 \mathrm{kHz} / 3 \mathrm{~h}$ & $60 \pm 15$ & $70 \pm 12$ \\
Base material & $110 \pm 4$ & $-10 \pm 1$ \\
\hline
\end{tabular}

temperatures lower than the first ageing temperature showed higher low and high cycle fatigue life. Data from Table 5, for experiment $(10.0 \mathrm{kV} / 0.1 \mathrm{kHz} / 2 \mathrm{~h})$ with PII treatment temperature of $116.8^{\circ} \mathrm{C}$ and surface microhardness of $181 \mathrm{HV}$, displayed an increase in the average rotating bending fatigue strength in comparison to base material.

Nanohardness measurements as a function of depth for base material and $(5.0 \mathrm{kV} / 1.0 \mathrm{kHz} / 2 \mathrm{~h}) /(10.0 \mathrm{kV} / 0.1 \mathrm{kHz} / 2 \mathrm{~h})$ PIII treatments are represented in Table 6 .

The implantation of nitrogen ions near surface and precipitations rearrangement through the diffusion caused by variation in temperature, occurred due to the $(10.0 \mathrm{kV} / 0.1 \mathrm{kHz} / 2 \mathrm{~h})$ PIII treatment. Therefore, a barrier to dislocations movement during plastic deformation caused by the interaction between precipitates rearrangement and cristaline structure distortion by nitrogen atoms resulted, as consequence, in an improvement in mechanical strength [18]. The increase in microhardness and nanohardness is related to the formation of an AlN layer, identified by DRX analyses, responsible for the resistance to fatigue crack nucleation at surface.

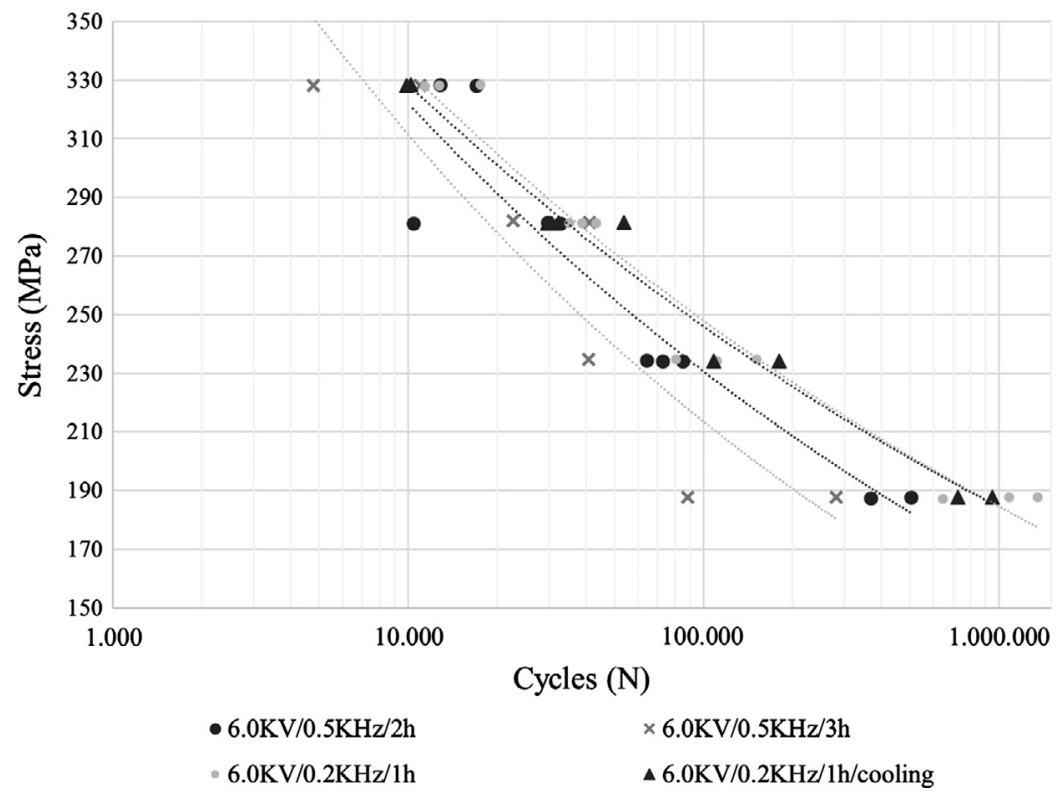

Fig. 4. S-N curves. $(6.0 \mathrm{kV} / 0.5 \mathrm{kHz} / 2 \mathrm{~h}),(6.0 \mathrm{kV} / 0.5 \mathrm{kHz} / 3 \mathrm{~h}),(6.0 \mathrm{kV} / 0.2 \mathrm{kHz} / 1 \mathrm{~h})$ and $(6.0 \mathrm{kV} / 0.2 \mathrm{kHz} / 1 \mathrm{~h} / \mathrm{cooling})$.

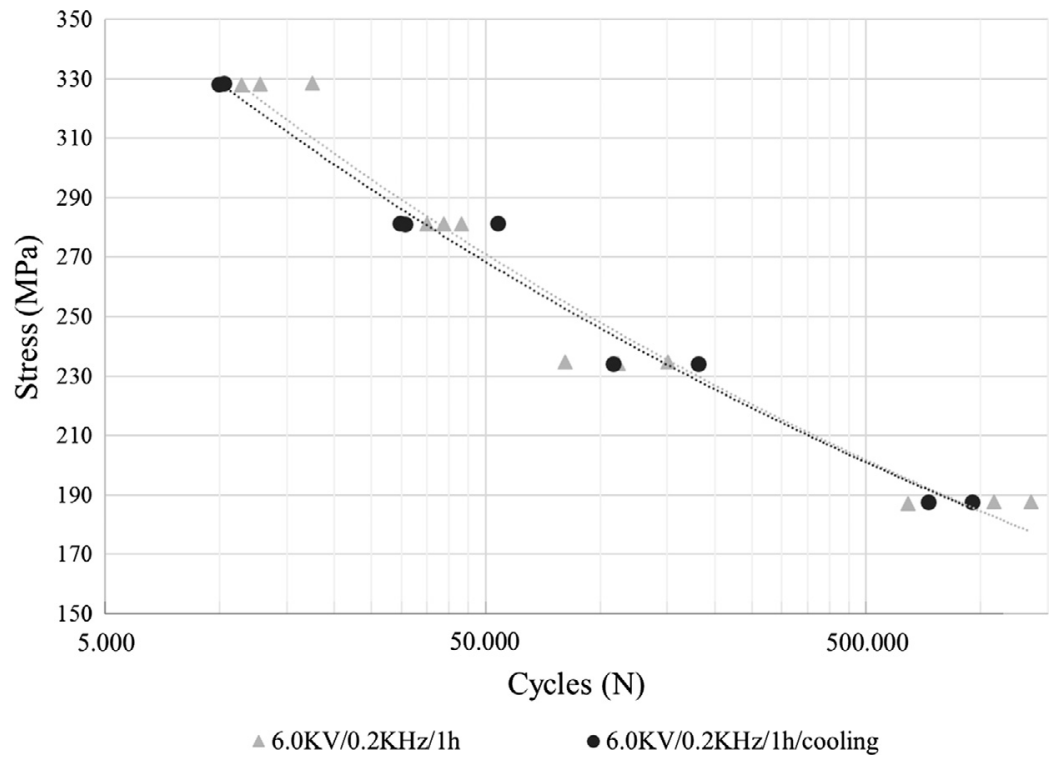

Fig. 5. S-N curves. $(6.0 \mathrm{kV} / 0.2 \mathrm{kHz} / 1 \mathrm{~h})$ and $(6.0 \mathrm{kV} / 0.2 \mathrm{kHz} / 1 \mathrm{~h} /$ cooling). 


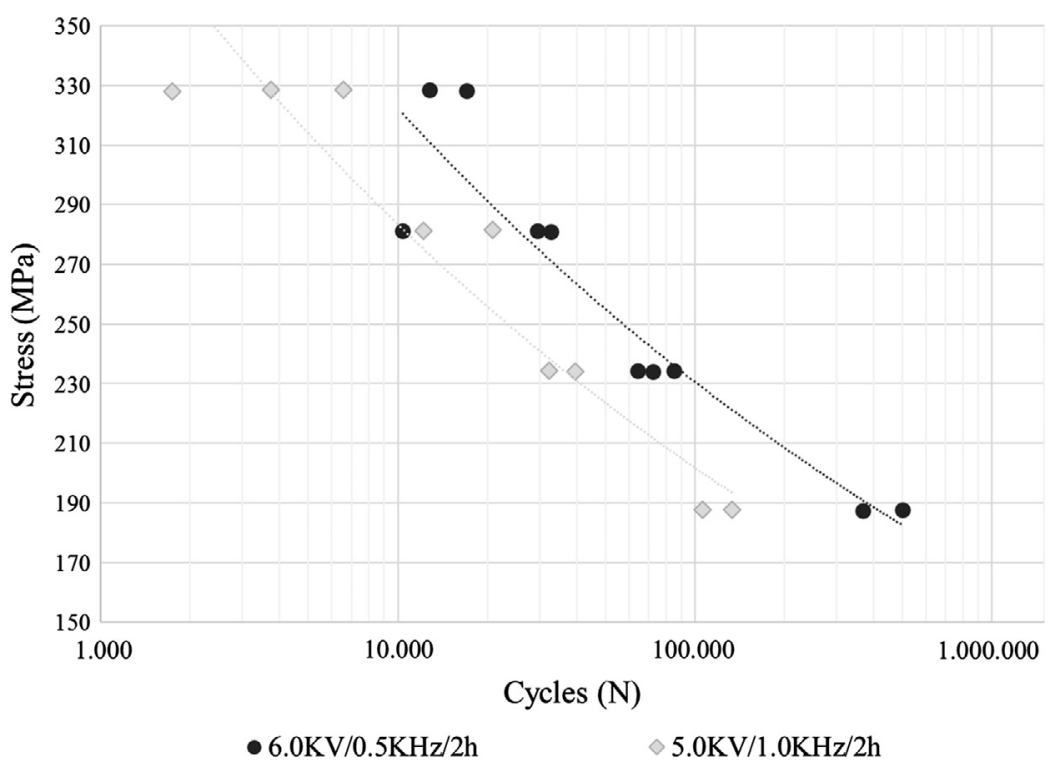

Fig. 6. S-N curves. $(6.0 \mathrm{kV} / 0.5 \mathrm{kHz} / 2 \mathrm{~h})$ and $(5.0 \mathrm{kV} / 1.0 \mathrm{kHz} / 2 \mathrm{~h})$.

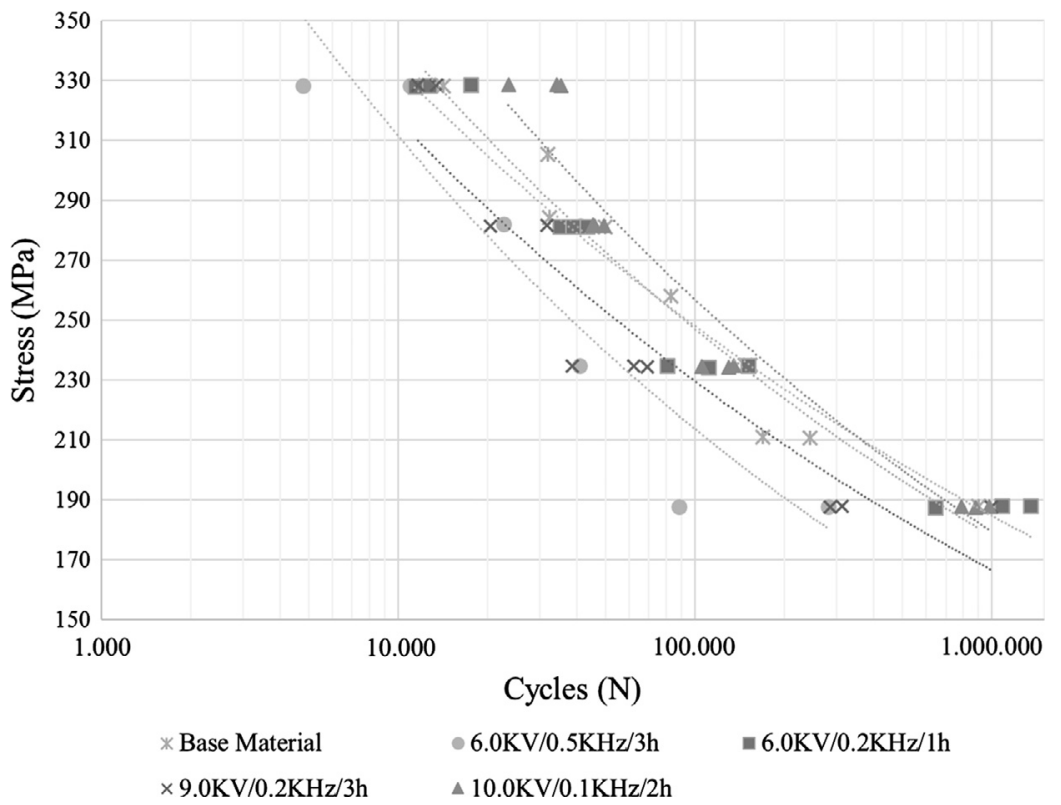

Fig. 7. S-N curves. $(6.0 \mathrm{kV} / 0.5 \mathrm{kHz} / 3 \mathrm{~h}),(6.0 \mathrm{kV} / 0.2 \mathrm{kHz} / 1 \mathrm{~h}),(9.0 \mathrm{kV} / 0.2 \mathrm{kHz} / 3 \mathrm{~h})$ and $(10.0 \mathrm{kV} / 0.1 \mathrm{kHz} / 2 \mathrm{~h})$.

According to Table 5 and Figs. 2 and 3, sulphuric and chromic anodizing processes reduced the fatigue resistance of AA 7050T7451 aluminum alloy.

Average coating thicknesses were, for sulphuric and chromic anodizing, $17.4 \mu \mathrm{m}$ and $12.9 \mu \mathrm{m}$, respectively. Just to compare, considering the average number of cycles to failure in Table 5, for $234 \mathrm{MPa}$ the reduction in fatigue life for sulphuric anodized specimens was $67 \%$, whereas for the chromic anodized the reduction was $44 \%$. The same fatigue tendency was observed by $[2,3,5]$.

Longitudinal and transversal residual stresses are indicated in Table 7.

From Table 7, longitudinal residual stresses for AA 7050-T7451, sulphuric and chromic anodizing were $110 \pm 4 \mathrm{MPa}, 100 \pm 7 \mathrm{MPa}$ and $-65 \pm 8 \mathrm{MPa}$, respectively.

Tensile residual stresses induce fatigue crack nucleation and propagation inside the coating layer. Compressive longitudinal residual stress $-65 \pm 8 \mathrm{MPa}$ is observed for AA 7050-T7451 chromic anodized. Despite the compressive residual stress, the chromic anodized coating reduces the fatigue performance compared to base material, considering hardness, porous and the presence of cracks when submitted to mechanical deformation.

Fig. 4 shows rotating bending $\mathrm{S}-\mathrm{N}$ curves for the following conditions: $(6.0 \mathrm{kV} / 0.5 \mathrm{kHz} / 2 \mathrm{~h}),(6.0 \mathrm{kV} / 0.5 \mathrm{kHz} / 3 \mathrm{~h}),(6.0 \mathrm{kV} / 0.2 \mathrm{kHz} / 1 \mathrm{~h})$ and $(6.0 \mathrm{kV} / 0.2 \mathrm{kHz} / 1 \mathrm{~h} /$ cooling).

From Table 5 and Fig. 4, experiments $(6.0 \mathrm{kV} / 0.2 \mathrm{kHz} / 1 \mathrm{~h})$ and (6.0 kV/0.2 kHz/1 h/cooling) showed higher fatigue strength in comparison to $(6.0 \mathrm{kV} / 0.5 \mathrm{kHz} / 2 \mathrm{~h})$ and $(6.0 \mathrm{kV} / 0.5 \mathrm{kHz} / 3 \mathrm{~h})$.

In case experiments $(6.0 \mathrm{kV} / 0.5 \mathrm{kHz} / 2 \mathrm{~h})$ and $(6.0 \mathrm{kV} / 0.5 \mathrm{kHz} / 3 \mathrm{~h})$, the increase in PIII treatment time from 2 to $3 \mathrm{~h}$ reduced the fatigue strength of base material. From Fig. 4, despite the difference in treatment times, increase in high cycle fatigue was obtained with the reduction in impact frequency from $0.5 \mathrm{kHz}$ to $0.2 \mathrm{kHz}$. 
It is also possible to conclude, from experimental data in Table 5 and Fig. 5, the negligible effect of cooling on the number of cycles to failure.

$\mathrm{S}-\mathrm{N}$ curves for experiments $(6.0 \mathrm{kV} / 0.5 \mathrm{kHz} / 2 \mathrm{~h})$ and $(5.0 \mathrm{kV} / 1.0 \mathrm{kHz} / 2 \mathrm{~h})$ are indicated in Fig. 6.

From Table 5 and Fig. 6, the detrimental effect of the increase in the impact frequency from $0.5 \mathrm{kHz}$ to $1.0 \mathrm{kHz}$ on the high cycle fatigue resistance, is represented.

Comparison between experiments $(6.0 \mathrm{kV} / 0.2 \mathrm{kHz} / 1 \mathrm{~h})$ and $(9.0 \mathrm{kV} / 0.2 \mathrm{kHz} / 3 \mathrm{~h})$ in Fig. 7 , shows the negative effect of the increase in voltage and time on the rotating bending fatigue strength of PIII treated AA 7050-T7451 aluminum alloy.

From experiments $(6.0 \mathrm{kV} / 0.5 \mathrm{kHz} / 3 \mathrm{~h})$ and $(9.0 \mathrm{kV} / 0.2 \mathrm{kHz} / 3 \mathrm{~h})$, despite the reduction in applied voltage, the increase in impact frequency played an important role on the fatigue behavior of PIII treated base material. It is important to remember that experiments $\quad(6.0 \mathrm{kV} / 0.5 \mathrm{kHz} / 3 \mathrm{~h}), \quad(9.0 \mathrm{kV} / 0.2 \mathrm{kHz} / 3 \mathrm{~h})$, $(5.0 \mathrm{kV} / 1.0 \mathrm{kHz} / 2 \mathrm{~h})$ and $(6.0 \mathrm{kV} / 0.5 \mathrm{kHz} / 2 \mathrm{~h})$ resulted in lower microhardness in comparison to base material. Experiment $(10.0 \mathrm{kV} / 0.1 \mathrm{kHz} / 2 \mathrm{~h})$ was performed to study the effect of low impact frequency on the S-N curve. The chamber temperature after $2 \mathrm{~h}$ PIII treatment was $116^{\circ} \mathrm{C}$; surface microhardness equal to $181 \mathrm{HV}$ and an improvement in fatigue strength was observed.

Residual stresses associated to the PIII treatments show an interesting tendency. Longitudinal and transversal residual stresses are compressive in experiments with impact frequency equal to $0.5 \mathrm{kHz}$ and $1.0 \mathrm{kHz}$. Experiments performed with impact frequency equal to $0.2 \mathrm{kHz}$ resulted in compressive longitudinal residual stress and tensile transversal residual stress $(6.0 \mathrm{kV} / 0.2 \mathrm{kHz} / 1$ $\mathrm{h} /$ cooling) or both tensile stresses $(9.0 \mathrm{kV} / 0.2 \mathrm{kHz} / 3 \mathrm{~h})$ and $(6.0 \mathrm{kV} / 0.2 \mathrm{kHz} / 1 \mathrm{~h})$.

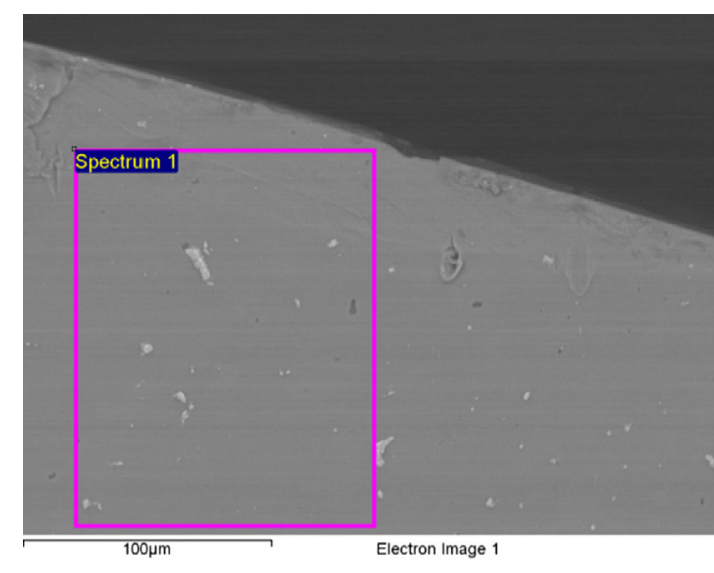

(a) $\begin{array}{cc} \\ \\ \end{array}$

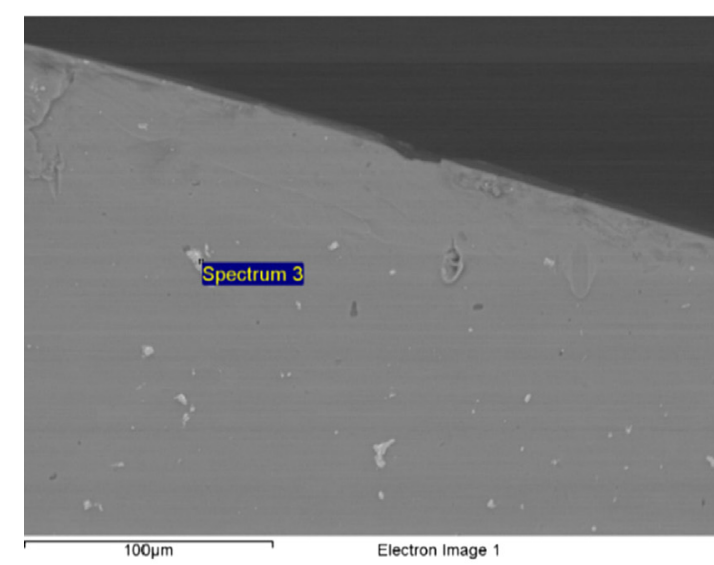

(b)

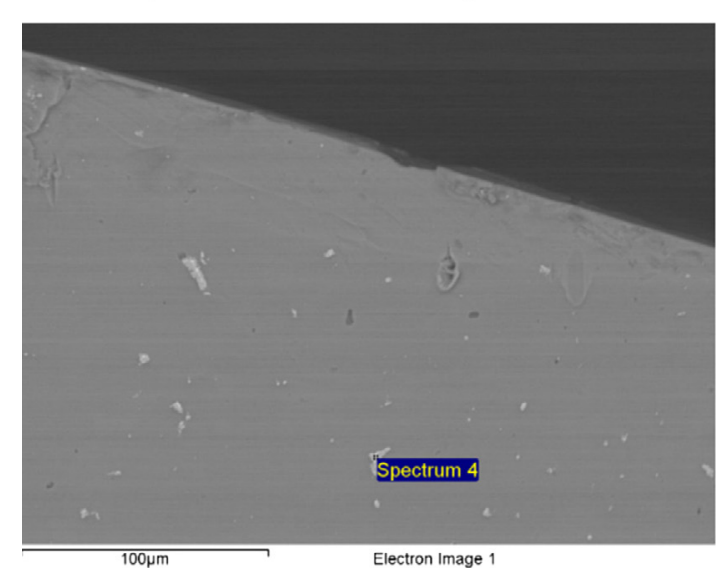

(c)

\begin{tabular}{ccc}
\hline Element & \% weight & \% Atômic \\
O K & 1.77 & 3.57 \\
$\mathrm{Mg} \mathrm{K}$ & 0.72 & 0.95 \\
$\mathrm{Al} \mathrm{K}$ & 66.17 & 78.93 \\
$\mathrm{Si} \mathrm{K}$ & 0.16 & 0.19 \\
$\mathrm{Fe} \mathrm{K}$ & 8.49 & 4.89 \\
$\mathrm{Ni} \mathrm{K}$ & 0.24 & 0.13 \\
$\mathrm{Cu} \mathrm{K}$ & 20.46 & 10.37 \\
$\mathrm{Zn} \mathrm{K}$ & 1.98 & 0.97 \\
\hline
\end{tabular}

$\begin{array}{ccc}\text { Element } & \text { \% weight } & \text { \% Atômic } \\ \text { Al K } & 56.35 & 74.55 \\ \text { Fe K } & 12.13 & 7.75 \\ \text { Ni K } & 0.41 & 0.25 \\ \text { Cu K } & 29.6 & 16.66 \\ \text { Zn K } & 1.45 & 0.79\end{array}$

Fig. 8. EDS analysis. Base material. 
As mentioned, sulphuric and chromic anodizing processes decrease the rotating bending fatigue strength of AA 7050-T7451 aluminum alloy. Coating hardness and the presence of cracks are related to this behavior. Sulphuric anodizing showed to be the worse condition. Reduction in the base material fatigue life is also observed for most of the PIII experiments studied. From Table 5, the treatment condition $(5.0 \mathrm{kV} / 1.0 \mathrm{kHz} / 2 \mathrm{~h})$ resulted in a significantly negative influence on the fatigue performance of the aluminum alloy. The decrease in life was even higher than for both anodizing processes. It is important to mention that $1.0 \mathrm{kHz}$ was the highest impact frequency studied. The fatigue life of AA 7050-T7451 aluminum alloy was reduced by experiments $(6.0 \mathrm{kV} / 0.5 \mathrm{kHz} / 2 \mathrm{~h})$ and $(6.0 \mathrm{kV} / 0.5 \mathrm{kHz} / 3 \mathrm{~h})$. The increase in treatment time from 2 to $3 \mathrm{~h}$ was detrimental with respect to the number of cycles to failure. The influence increases in the high cycle fatigue regime. The parameters impact frequency and treatment time played an important role on the effect of the PIII treatment. Both experiments, $(6.0 \mathrm{kV} / 0.2 \mathrm{kHz} / 1 \mathrm{~h})$ and $(6.0 \mathrm{kV} / 0.2 \mathrm{kHz} / 1 \mathrm{~h} /$ cooling) showed fatigue strength higher than those obtained from the anodizing processes. Almost the same fatigue performance was obtained with and without the cooling operation.

Experiment with the lowest impact frequency $(10.0 \mathrm{kV} / 0.1 \mathrm{kHz} / 2 \mathrm{~h})$ increased the rotating bending fatigue life in comparison to AA 7050-T7451 aluminum alloy.

EDS analysis were performed with AA 7050-T7451 aluminum alloy samples in experimental conditions $(5.0 \mathrm{kV} / 1.0 \mathrm{kHz} / 2 \mathrm{~h}) /$ $(10.0 \mathrm{kV} / 0.1 \mathrm{kHz} / 2 \mathrm{~h})$ to characterize surfaces with respect to properties and chemical composition. Fig. 8a, b and c showed base material EDS analysis of some regions and precipitates.

In Fig. 8a, elements and respective weight (\%) correspond, approximately, to results obtained in the performed base material chemical analysis. In Fig. 8b, the presence of precipitates $\mathrm{Al}_{2} \mathrm{CuMg}$ and $\mathrm{Al}_{7} \mathrm{Cu}_{2} \mathrm{Fe}$ are observed and in Fig. $8 \mathrm{c}$, only precipitates $\mathrm{Al}_{7} \mathrm{Cu}_{2} \mathrm{Fe}$ are indicated [19].

In Fig. 9, EDS results for PIII treatment with experimental parameters $(5.0 \mathrm{kV} / 1.0 \mathrm{kHz} / 2 \mathrm{~h})$ are represented.

The highest initial and maximum treatment temperatures, respectively $111.3^{\circ} \mathrm{C}$ and $242.1^{\circ} \mathrm{C}$ in comparison to all the PIII treatment conditions studied and presented in this paper, were responsible for the diffusion of precipitates and oxygen in the AA 7050-T7451 aluminum alloy surface. Heterogeneous aluminum oxide $\left(\mathrm{Al}_{2} \mathrm{O}_{3}\right)$ and aluminum nitride (AIN) layers contributed to the nucleation of superficial cracks. The decrease in fatigue strength is associated to the improvement in the atomic diffusion and to an heterogeneous ceramic layer which, consequently, induce a surface rearrangement reducing micro and nanohardness of treated materials [20].

Higher surface micro and nanohardness and increase in fatigue life was observed for PIII treatment with experimental parameters ( $10.0 \mathrm{kV} / 0.1 \mathrm{kHz} / 2 \mathrm{~h})$. EDS and DRX analysis indicate, in this case, aluminum nitride (AIN) formation in specimen surface layer. Results are shown in Fig. 10.

Fatigue crack initiation at specimen surface is represented in Fig. 11a and b. Experimental test was performed with maximum

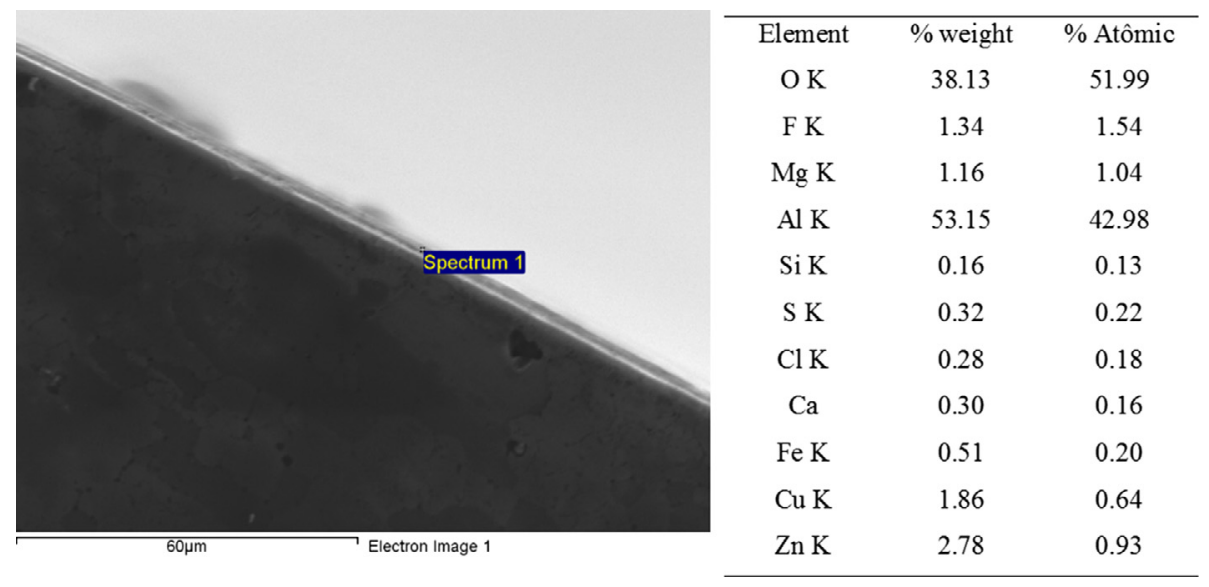

Fig. 9. EDS analysis. ( $5.0 \mathrm{kV} / 1.0 \mathrm{kHz} / 2 \mathrm{~h})$.

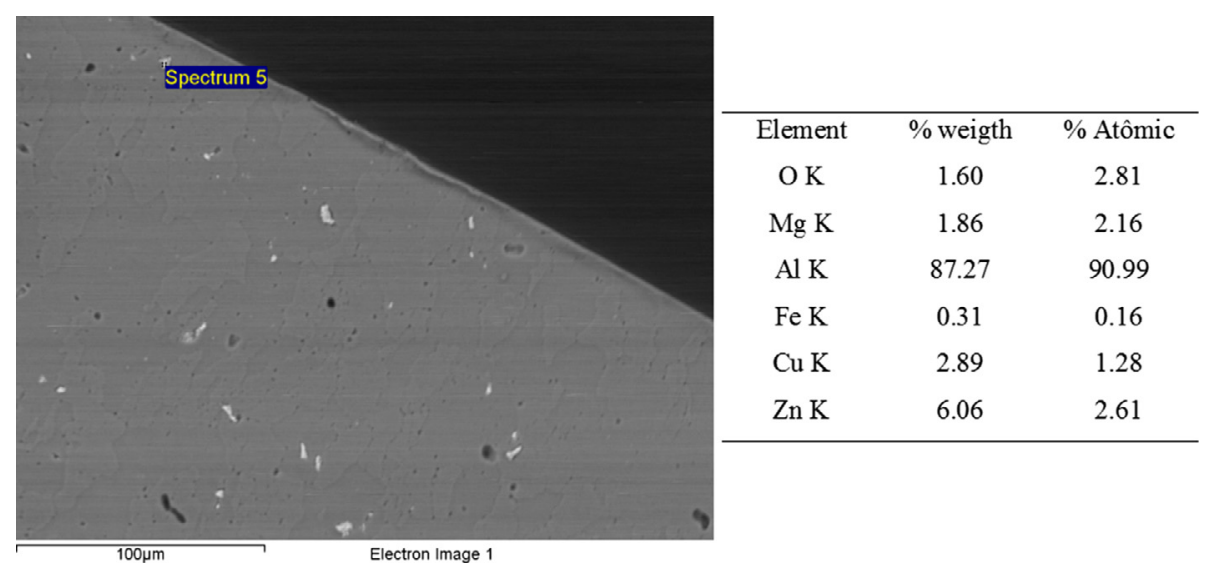

Fig. 10. EDS analysis. $(10.0 \mathrm{kV} / 0.1 \mathrm{kHz} / 2 \mathrm{~h})$. 


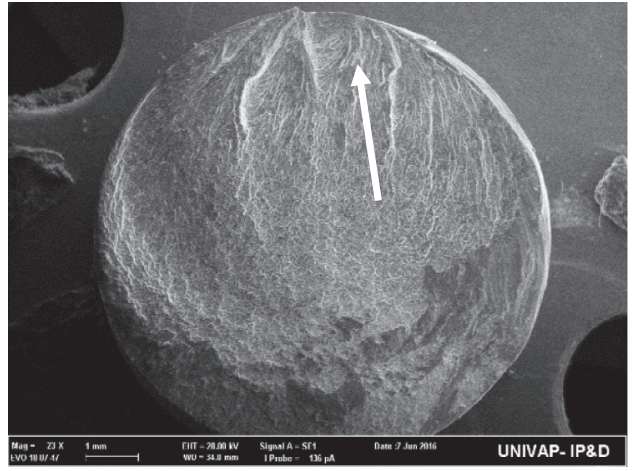

(a)

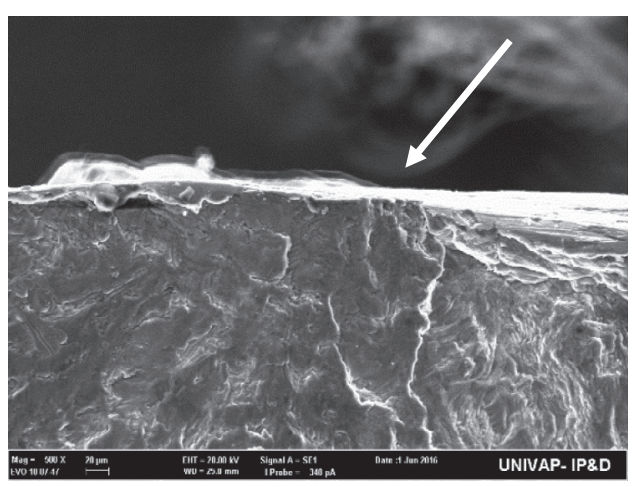

(b)

Fig. 11. Fatigue fracture surface. AA 7050-T7451 aluminum alloy.

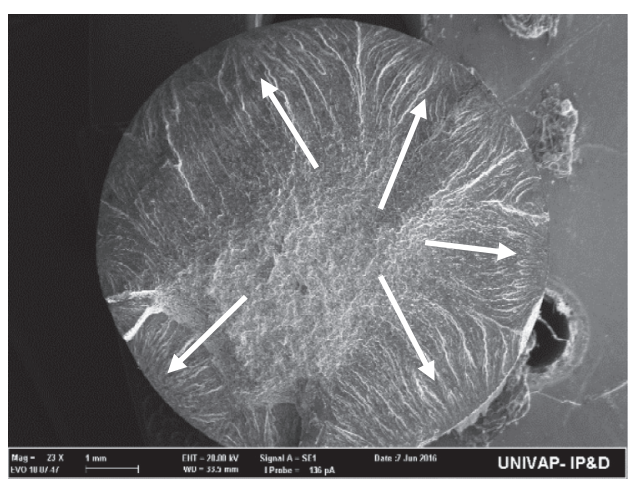

(a)

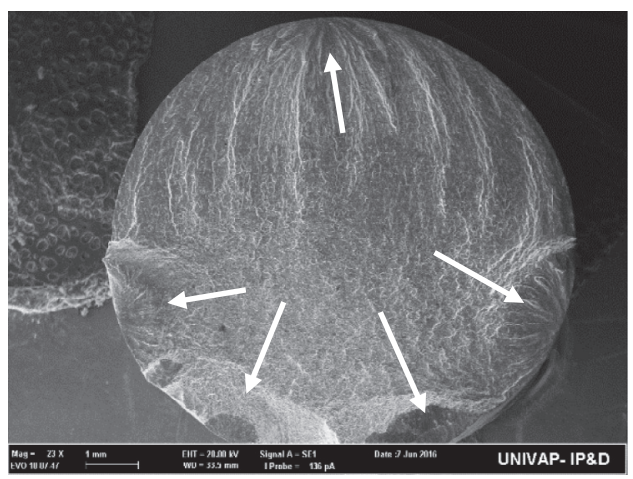

(b)

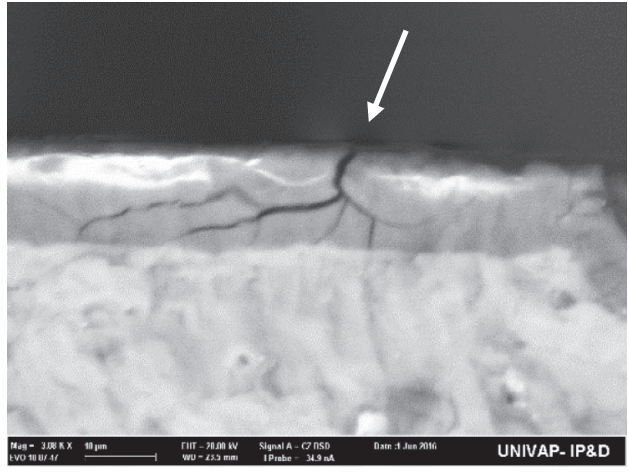

(c)

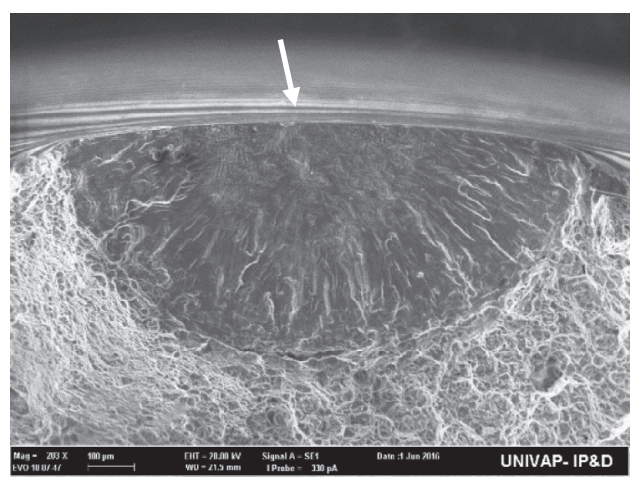

(d)

Fig. 12. Fatigue fracture surface (a) and (c) sulphuric anodization. (b) and (d) Chromic anodization.

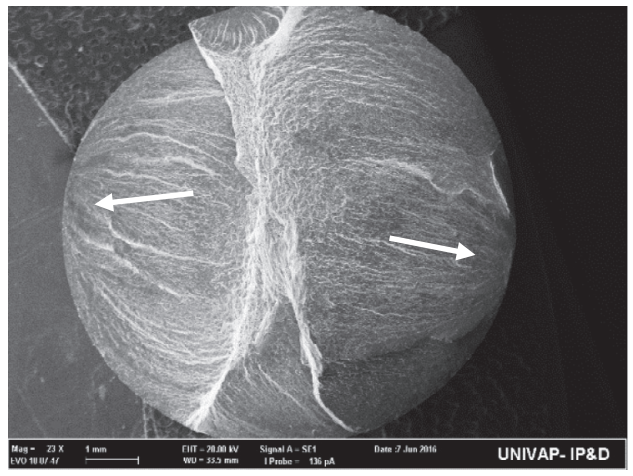

(a)

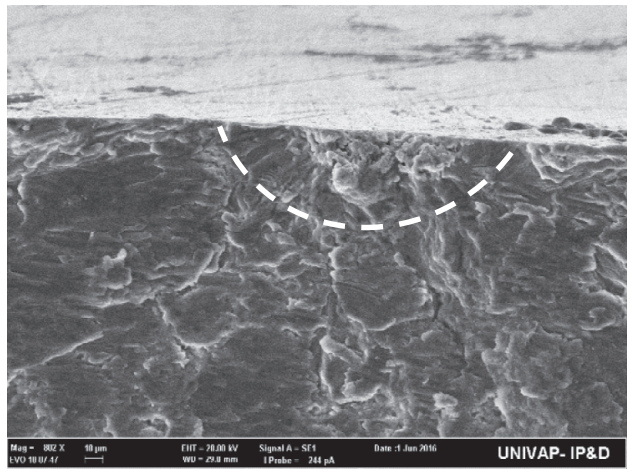

(b)

Fig. 13. Fatigue fracture surface. $(6.0 \mathrm{kV} / 0.5 \mathrm{kHz} / 2 \mathrm{~h}) . \sigma=234 \mathrm{MPa}, \mathrm{N}=72483$ cycles. 


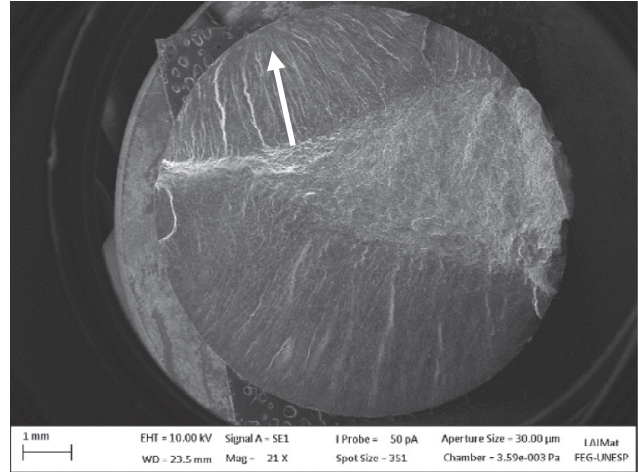

(a)

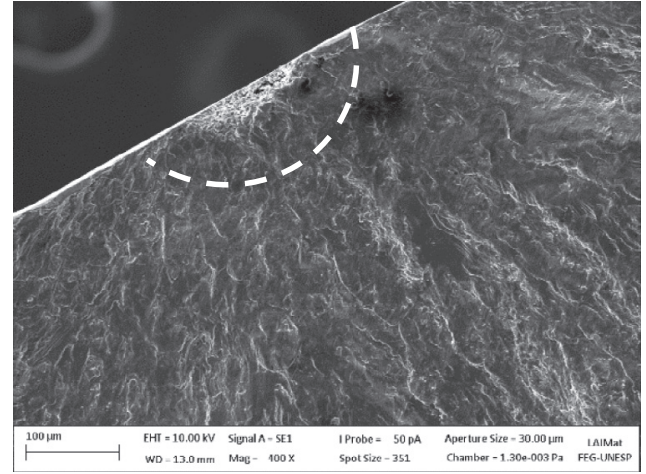

(b)

Fig. 14. Fatigue fracture surface. $(5.0 \mathrm{kV} / 1.0 \mathrm{kHz} / 2 \mathrm{~h}) . \sigma=234 \mathrm{MPa}, \mathrm{N}=35918$ cycles.

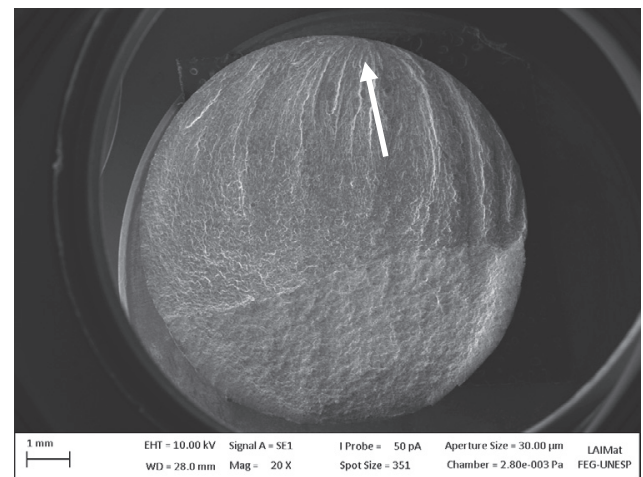

(a)

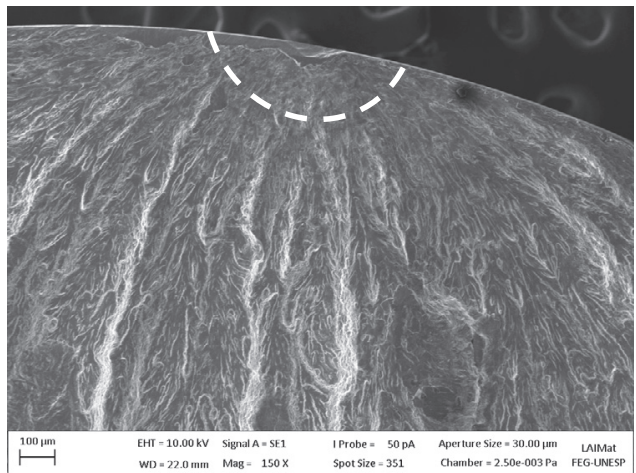

(b)

Fig. 15. Fatigue fracture surface $(10.0 \mathrm{kV} / 0.1 \mathrm{kHz} / 2 \mathrm{~h}) . \sigma=234 \mathrm{MPa}, \mathrm{N}=32971$ cycles.

stress $234 \mathrm{MPa}$ and 147361 cycles to failure. Fracture surfaces of specimens sulphuric and chromic anodized are represented in Fig. 12a and b, respectively. The maximum applied stress was $234 \mathrm{MPa}$ and number of cycles to failure were 47487 and 75648 , respectively. In Fig. 12c, crack starting from the sulphuric anodized layer is observed.

Fatigue crack initiation at specimen surface is represented in Fig. 13 for $(6.0 \mathrm{kV} / 0.5 \mathrm{kHz} / 2 \mathrm{~h})$ PII treatment.

It is interesting to observe in Fig. 14, which represents the fracture surface of a specimen $(5.0 \mathrm{kV} / 1.0 \mathrm{kHz} / 2 \mathrm{~h})$ PIII treatment, multiple fatigue crack sources around the specimen fracture surface. Fatigue fracture surface for experiments $(10.0 \mathrm{kV} / 0.1 \mathrm{kHz} / 2 \mathrm{~h})$ is indicated in Fig. 15.

\section{Conclusions}

Coating thicknesses from sulphuric and chromic anodizing were respectively, $17.4 \mu \mathrm{m}$ and $12.9 \mu \mathrm{m}$. Decrease in fatigue strength in comparison to AA 7050-T7451 aluminum alloy is attributed to the presence of microcracks and tensile residual stresses induced by the deposition process.

A direct relation between chamber temperature and experimental implantation frequency was observed for PIII treatments. For conditions $(6.0 \mathrm{kV} / 0.2 \mathrm{kHz} / 1 \mathrm{~h}),(6.0 \mathrm{kV} / 0.2 \mathrm{kHz} / 1 \mathrm{~h} /$ cooling) and $(10.0 \mathrm{kV} / 0.1 \mathrm{kHz} / 2 \mathrm{~h})$, maximum temperatures were lower than the first AA 7050-T7451 aluminum alloy ageing temperature $\left(115^{\circ}-125^{\circ} \mathrm{C}\right)$. Experimental parameters $(9.0 \mathrm{kV} / 0.2 \mathrm{kHz} / 3 \mathrm{~h})$ and $(6.0 \mathrm{kV} / 0.5 \mathrm{kHz} / 2 \mathrm{~h})$ resulted in PII treatment temperatures higher than the first ageing temperatures $\left(115^{\circ}-125^{\circ} \mathrm{C}\right)$, but lower than the second ageing temperature $\left(160^{\circ}-170^{\circ} \mathrm{C}\right)$ and $(6.0 \mathrm{kV} / 0.5 \mathrm{kHz} / 3 \mathrm{~h}),(5.0 \mathrm{kV} / 1.0 \mathrm{kHz} / 2 \mathrm{~h})$ with PIII treatments temperatures higher than the second ageing temperature.

Higher surface microhardness measurements in comparison to base material were obtained for PIII treatments in which maximum chamber temperature was lower than the first ageing temperature.

The influence of experimental implantation frequency in PIII treatments and, consequently, treatment temperature, is also observed in nanohardness measurements. Lower values were obtained for condition $(5.0 \mathrm{kV} / 1.0 \mathrm{kHz} / 2 \mathrm{~h})$, whereas higher nanohardness in comparison to AA 7050-T7451 aluminum alloy resulted from $(10.0 \mathrm{kV} / 0.1 \mathrm{kHz} / 2 \mathrm{~h})$ PIII treatment. Improvement in mechanical strength is associated to nitrogen ions implantation near surface and precipitation rearrangement, acting as a barrier to the dislocation movement during plastic deformation.

$\mathrm{X}$-ray diffraction analysis for PIII treatment with experimental parameters $(5.0 \mathrm{kV} / 1.0 \mathrm{kHz} / 2 \mathrm{~h})$ indicate increase in aluminum diffraction inducing particles agglomeration at sample surface due to high temperatures, with decrease in mechanical strength. The formation of AlN in cristalographic planes (100) and (101) and $\mathrm{Al}_{2} \mathrm{O}_{3}$ in cristalographic plane (110), as a result of PIII parameters $(10.0 \mathrm{kV} / 0.1 \mathrm{kHz} / 2 \mathrm{~h})$ with lower treatment temperatures, was responsible for improvement in the fatigue strength.

EDS analysis in experiments $(5.0 \mathrm{kV} / 1.0 \mathrm{kHz} / 2 \mathrm{~h})$ indicate heterogeneous $\mathrm{Al}_{2} \mathrm{O}_{3}$ and AlN layers, responsible for superficial cracks. Decrease in fatigue strength is associated to increase in atomic difusion and the presence of heterogeneous ceramic layer. 
On the other hand, the low temperature from experiment $(10.0 \mathrm{kV} / 0.1 \mathrm{kHz} / 2 \mathrm{~h})$ was responsible for a more homogeneous ceramic layer resulting from the particles impact on surface and also an homogeneous element distribution in structure.

Longitudinal and transversal residual stresses are compressive in experiments with impact frequency equal to $0.5 \mathrm{kHz}$ and $1.0 \mathrm{kHz}$. Experiments performed with impact frequency equal to $0.2 \mathrm{kHz}$ resulted in compressive longitudinal residual stress and tensile residual stress or both tensile stresses.

Fracture surface analysis indicate multiple fatigue crack initiation in PIII treatments with higher impact frequency $(6.0 \mathrm{kV} / 0.5 \mathrm{kHz} / 3 \mathrm{~h}),(6.0 \mathrm{kV} / 0.5 \mathrm{kHz} / 2 \mathrm{~h})$ and $(5.0 \mathrm{kV} / 1.0 \mathrm{kHz} / 2 \mathrm{~h})$.

\section{Acknowledgements}

The author H. J. C. Voorwald is grateful to CNPq, process number 303832/2014-2.

The authors are grateful for this research support by Maria da Penha Cindra Fonseca.

\section{References}

[1] Shih T, Chiu Y. Corrosion resistance and high-cycle fatigue strength of anodized/sealed AA7050 and AA7075 alloys. Appl Surf Sci 2015;351:997-1003.

[2] Camargo JAM, Voorwald HJC, Cioffi MOH, Costa MYP. Coating residual stress effects on fatigue performance of 7050-T7451 aluminum alloy. Surf Coat Technol 2007:201:9448-55.

[3] Shahzad M, Chaussumier M, Chieragatti R, Mabru C, Rezai-Aria F. Surface characterization and influence of anodizing process on fatigue life of $\mathrm{Al} 7050$ alloy. Mater Des 2011;32:3328-35.

[4] Chaussumier M, Mabru C, Chieragatti R, Shahzad M. Fatigue life model for 7050 chromic anodized aluminum alloy. Procedia Eng 2013;6:300-12.

[5] Shahzad M, Chaussumier M, Chieragatti R, Mabru C, Rezai-Aria F. Influence of surface treatments on fatigue life of Al 7010 Alloy. J Mater Process Technol 2010;210:1821-6.
[6] Savaria V, Bridier F, Bocher P. Predicting the effects of material properties gradient and residual stresses on the bending fatigue strength of induction hardened aeronautical gears. Int J Fatigue 2016;85:70-84.

[7] Zang Q, Wang W. Study of anodizing behavior and corrosion resistance of $7050 T 7451$ alloy. Mater Sci Eng 2000;280:168-72.

[8] Chaussumier M, Mabru C, Shahzad M, Chieragatti R, Rezai-Aria F. A predictive fatigue life model for anodized 7050 aluminum alloy. Int J Fatigue 2013;48:205-13.

[9] Shahzad M, Chaussumier M, Chieragatti R, Mabru C, Rezai-Aria F. Influence of anodizing process on fatigue life of machined aluminum alloy. Procedia Eng 2010;2:1015-24.

[10] Oguri K. Fatigue life enhancement of aluminum alloy for aircraft by fine particle shot peening (FPSP). J Mater Process Technol 2011;211:1395-9.

[11] Torres MAS, Voorwald HJC. An evaluation of shot peening, residual stress and stress relaxation on the fatigue life of AISI 4340 steel. Int J Fatigue 2002:24:877-86.

[12] Tian X, Fu RYY, Chu PK. Effects of bias voltage on the corrosion resistance of titanium nitride thin films fabricated by dynamic plasma immersion ion implantation-deposition. J Vac Sci Technol 2002;20.

[13] Kostov KG, Ueda M, Tan IH, Leite NF, Beloto AF, et al. Structural effect of nitrogen plasma-based ion implantation on ultra-high molecular weight polyetilene. Surf Coat Technol 2004;186:287-90.

[14] Wilbur PJ, Buchholtz BW. Engineering tribological surfaces by ion implantation. Surf Coat Technol 1996;79:1-8.

[15] Fernandes BB, Mandl S, Oliveira RM, Ueda M. Mechanical properties of nitrogen-rich surface layers on SS304 treated by plasma immersion ion implantation. Appl Surf Sci 2014;310:278-83.

[16] Wang SY, Chu PK, Tang BY, Yan JC, Zeng XC. Improvement of wear and corrosion resistance of oil pump materials using immersion ion implantation. Surf Coat Technol 1998;98:897-900.

[17] Liu H, Tang B, Wang L, Wang X, Jiang B. Fatigue life and mechanical behaviors of bearing steel by nitrogen plasma immersion ion implantation. Surf Coat Technol 2007;201:5273-7.

[18] Totten GE, Mackenzie DS. Handbook of aluminum: physical metallurgy and processes. New York: EUA; 2003. v. 1.

[19] Liu Y, Li W, Jiang D. The effect of pre-ageing on the microstructure and properties of 7050 alloy. J Mater Res 2015;30(24):3803-10.

[20] Deng C, Wang H, Gongo B, Li X, Lei Z. Effects of microstructural heterogeneity on very high cycle fatigue properties of 7050-T7451 aluminum alloy friction stir butt welds. Int J Fatigue 2016;83:100-8. 